REGARDLESS OF FRONTIERS 



\section{Regardless of Frontiers}

Global Freedom of Expression in a Troubled World

\section{Edited by \\ Lee C. Bollinger \\ and \\ Agnès Callamard}

COlumbia university Press 
Columbia University Press

Publishers Since 1893

New York Chichester, West Sussex cup.columbia.edu Copyright (C) 2021 Columbia University Press All rights reserved

Library of Congress Cataloging-in-Publication Data

Names: Bollinger, Lee C., 1946- editor. | Callamard, Agnès, editor. Title: Regardless of frontiers : global freedom of expression in a troubled world / edited by Lee C. Bollinger, Agnès Callamard.

Description: New York : Columbia University Press, [2021] | Includes bibliographical references and index. Identifiers: LCCN 2020026141 (print) | LCCN 2020026142 (ebook) | ISBN 9780231196987 (hardback) | ISBN 9780231196994 (trade paperback) | ISBN 9780231551922 (ebook) Subjects: LCSH: Freedom of expression. | Freedom of speech. | Sovereignty. | European Court of Human Rights. Classification: LCC K3253 .R44 2021 (print) | LCC K3253 (ebook) | DDC $341.4 / 833-\mathrm{dc} 23$

LC record available at https://lccn.loc.gov/2020026141 LC ebook record available at https://lccn.loc.gov/2020026142

Columbia University Press books are printed on permanent and durable acid-free paper. Printed in the United States of America 
We dedicate this book to all those women and men around the world who are standing up in courtrooms and newsrooms, in the academy and in international organizations, in exercise of their freedom of expression and information and in defense of ours. 
